\title{
Precipitin reaction between serum and lysed erythrocytes
}

\author{
J. F. WILSON AND GILLIAN WARREN \\ From the Department of Pathology, Royal Infirmary, Sunderland
}

SYNOPSIS The albumin fraction of all normal sera contains a factor which precipitates with part of the normal haemoglobin molecule, the reaction occurring in the proportions of $1 \mathrm{ml}$. serum to 6 to $15 \mathrm{mg}$. haemoglobin.

A substance in normal human and animal sera, which formed a precipitate in agar gel with lysates of normal human erythrocytes but which gave little precipitate in fluid media, was described by Peetoom, Rose, Ruddy, Micheli, and Grabar (1960). They thought that this substance was possibly haptoglobin. However, Wilson and Jobling (1961) found that the precipitate is formed not only in agar gel but also when the haemolysate is added to serum in tubes at $37^{\circ} \mathrm{C}$. The reaction occurs between serum and the isologous or other human haemolysates and cross-precipitation also occurs between human and some animal sera and haemolysates. The reaction is independent of the $\mathrm{ABO}$ blood groups and haptoglobins.

A more detailed analysis of the factors involved in the reaction is presented in this paper.

\section{MATERIALS AND METHODS}

SERUM AND PLASMa Serum is Seitz filtered after separation. Plasma is removed aseptically from citrated blood. Contamination by lysed erythrocytes is avoided.

As serum or plasma can be used for these tests without affecting the results, 'serum' is used throughout the text to denote either serum or plasma.

HAEMOLYSATE Haemolysate is prepared from citrated blood. The erythrocytes are washed in $0.9 \%$ saline until the supernatant is clear after centrifuging. The cells are frozen at $-10^{\circ} \mathrm{C}$. and lysed by thawing. Haemoglobin in the lysate is estimated colorimetrically and diluted with distilled water to the concentration required. The lysate is then Seitz filtered.

PRECIPITATION IN AGAR GeL Ouchterlony's technique, with agar-coated microscope slides, is used.

Received for publication 11 July 1961.
PRECIPITATION IN TUBES Sterile serum and lysate are $\bar{c}$ mixed and incubated at $37^{\circ} \mathrm{C}$. for three days in sterile tubes. The mixture is centrifuged and the supernatant removed for testing in agar gel. The precipitate is washed once in normal saline, once in distilled water, dried for $\vec{\theta}$ 48 hours at $90^{\circ} \mathrm{C}$., and weighed. Very small precipitates are washed once in normal saline, suspended in distilled water, and measured turbimetrically.

IRON CONTENT OF THE PRECIPITATE This is estimated by a modification of Trinder's (1956) method. The tubes are cleaned with nitric and perchloric acids. The precipitate is digested by heating with $0.2 \mathrm{ml}$. concentrated nitric acid and $0.1 \mathrm{ml} .60 \% \mathrm{w} / \mathrm{w}$ perchloric acid for three hours $\overline{\bar{O}}$ at $200^{\circ} \mathrm{C}$. Colour is developed with $3 \mathrm{ml}$. water, $0.8 \mathrm{ml}$. $3 \mathrm{M}$ sodium acetate, $0.5 \mathrm{ml}$. $0.1 \%$ sulphonated $4: 7$ diphenyl 1:10 phenanthroline, $0.05 \mathrm{ml}$. thioglycollic acid, and $0.4 \mathrm{ml} .50 \% \mathrm{v} / \mathrm{v}$ sulphuric acid.

ALBUMIN Albumin is prepared by selective precipitation $\overline{0}$ of the serum globulin by $28 \%$ sodium sulphite $\left(\mathrm{Na}_{2} \mathrm{SO}_{3}\right)$ or by trichloracetic acid as described by Debro, Tarver, $\delta$ and Korner (1957).

\section{RESULTS}

PRECIPITATION IN AGAR GEL Two hundred and eighty-nine normal human sera reacted with $\bar{N}$ lysates of human erythrocytes to form a well-marked ज precipitin band in agar gel. This occurred even with $N$ the isologous serum and lysate. With suitable pro- $N$ portions of some sera and lysates the single broad band was divided (Fig. 1).

Sera diluted with normal saline lost their ability $\frac{\mathscr{D}}{\Phi}$ to form this precipitate. Of 101 normal sera, 10 had $\stackrel{\oplus}{+}$ a titre of 1 in 8, 29 of 1 in 16, and 62 of 1 in 32. The titres of eight sera from people over 70 years of age were similar, five of 1 in 16 and three of 1 in 32 .

Heating four sera at $56^{\circ} \mathrm{C}$. for one hour to destroy $\mathbb{D}$ complement did not affect the formation of the 


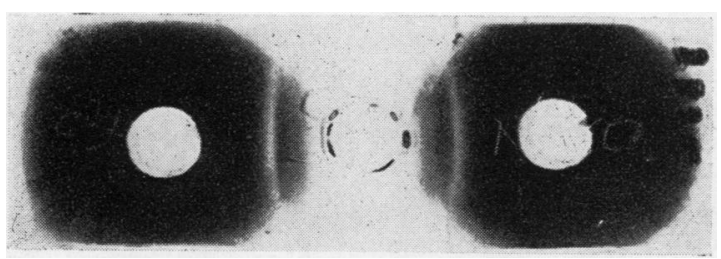

FIG. 1 Precipitin bands formed in agar gel by serum and haemoglobin.

Haemoglobin I

Serum II Haemoglobin III Stained azo-carmine

precipitate in agar gel nor the titres of the sera. The precipitate was not formed at $4^{\circ} \mathrm{C}$.

PRECIPITATING FACTOR AND ABO BLOOD GROUPS Four sera of each ABO blood group tested in agar gel with lysate from each group formed similar precipitin bands.

Eight sera were tested with lysate from the corresponding group. The anti-A and anti-B agglutinins were completely absorbed with washed intact erythrocytes and the sera retested. With all sera the precipitin bands were similar before and after absorption.

The precipitating factor was completely absorbed from eight sera with lysate from different groups; this absorption did not remove the $\mathrm{ABO}$ agglutinins.

PRECIPITATION IN FLUID MEDIA Lysate and serum mixture in tubes at $37^{\circ} \mathrm{C}$. continued to form a precipitate for about six days but most was formed within three days. If less than $15 \mathrm{mg}$. haemoglobin was added to $1 \mathrm{ml}$. serum, the precipitate was offwhite in colour. Larger amounts of haemoglobin coloured the precipitate.

Lysate containing $1 \%$ haemoglobin was layered on to 12 normal sera in capillary tubes and incubated at $37^{\circ} \mathrm{C}$. The tubes were examined every five minutes and precipitates appeared after 40 to 120 minutes, nine within 60 minutes.

PRECIPITATE FROM VARYING AMOUNTS OF HAEMOGLOBIN AND CONSTANT AMOUNT OF SERUM Increasing amounts of haemoglobin $(3,6,10,12,15$, and
20 mg.) were added to a series of tubes containing a constant volume of a serum $(1 \mathrm{ml}$.). Seven haemoglobins were tested with the same normal serum (Table) and 22 normal sera were tested with different hae.noglobins. In all tests the precipitate increased with increasing haemoglobin. After 6 to $15 \mathrm{mg}$. haemoglobin had been added, depending upon the serum, the increase in the precipitate became less marked. Four sera were tested with lysate containing up to 80 or $160 \mathrm{mg}$. haemoglobin per $1 \mathrm{ml}$. serum. The amount of precipitate was not greatly affected by the addition of more haemoglobin.

The supernatant from each tube was examined for its capacity to precipitate with more lysate or serum in agar gel. The first tubes of each series showed excess serum and the last tubes excess lysate. The change from excess serum to excess lysate occurred at about the point at which the amount of precipitate ceased to increase rapidly.

This test also showed that after three days' incubation at $37^{\circ} \mathrm{C}$. the factor responsible for precipitation was absorbed from $1 \mathrm{ml}$. of most of 47 normal sera by about $10 \mathrm{mg}$. haemoglobin; seven required $9 \mathrm{mg}$. haemoglobin, $3210 \mathrm{mg}$., five $12 \mathrm{mg}$., and three $15 \mathrm{mg}$.

PRECIPITATE FROM VARYING AMOUNTS OF SERUM AND CONSTANT AMOUNT OF HAEMOGLOBIN A similar series of tests was made by adding increasing amounts of a serum $(0.25,0.5,0.75,1.0,1.5,2.0$, $2.5 \mathrm{ml}$.) to tubes containing a constant amount of haemoglobin $(10 \mathrm{mg}$.). With eight normal sera the precipitates increased with increasing serum, the increase becoming less marked at the end of the range. The supernatant fluids were tested in agar gel; those from the first tubes had an excess of haemoglobin, those from the latter tubes an excess of serum. In this series the factor responsible for precipitation was absorbed from $10 \mathrm{mg}$. haemoglobin by $1 \mathrm{ml}$. of three sera and $1.5 \mathrm{ml}$. of five sera.

DANYSZ PHENOMENON As in some antigen-antibody systems neutralization depends upon the way in which the antigen is added to the antibody, haemoglobin was added in equivalent and fractional

TABLE

VARYING AMOUNTS OF SEVEN DIFFERENT HAEMOGLOBINS ADDED TO A CONSTANT VOLUME OF THE SAME SERUM

\begin{tabular}{|c|c|c|c|c|c|c|c|c|}
\hline Hb added (mg. per $m l)$. & & 3 & 6 & 9 & 10 & 12 & 15 & 20 \\
\hline $\begin{array}{l}\text { Haemoglobin I } \\
\text { Haemoglobin II } \\
\text { Haemoglobin III } \\
\text { Haemoglobin IV } \\
\text { Haemoglobin V } \\
\text { Haemoglobin VI } \\
\text { Haemoglobin VII }\end{array}$ & $\begin{array}{l}\text { Weight of } \\
\text { precipitate (mg.) }\end{array}$ & $\begin{array}{l}4 \cdot 8 \\
3 \cdot 4 \\
4 \cdot 1 \\
3 \cdot 8 \\
3 \cdot 6 \\
2 \cdot 1 \\
2 \cdot 6\end{array}$ & $\begin{array}{l}7 \cdot 0 \\
4 \cdot 0 \\
6 \cdot 5 \\
6 \cdot 0 \\
5 \cdot 4 \\
3 \cdot 7 \\
5 \cdot 4\end{array}$ & $\begin{array}{l}7 \cdot 8 \\
7 \cdot 2 \\
9 \cdot 1 \\
7 \cdot 0 \\
7 \cdot 8 \\
5 \cdot 7 \\
7 \cdot 0\end{array}$ & $\begin{array}{r}8 \cdot 2 \\
6 \cdot 6 \\
8 \cdot 7 \\
7 \cdot 0 \\
10 \cdot 4 \\
5 \cdot 7 \\
7 \cdot 0\end{array}$ & \begin{tabular}{r|}
$8 \cdot 0$ \\
$7 \cdot 8$ \\
$9 \cdot 9$ \\
$7 \cdot 8$ \\
$11 \cdot 1$ \\
$6 \cdot 4$ \\
$8 \cdot 0$
\end{tabular} & $\begin{array}{r}9 \cdot 3 \\
10 \cdot 2 \\
11 \cdot 5 \\
7 \cdot 8 \\
13 \cdot 6 \\
7 \cdot 6 \\
10 \cdot 2\end{array}$ & $\begin{array}{r}10 \cdot 5 \\
13 \cdot 2 \\
10 \cdot 8 \\
13 \cdot 7 \\
9 \cdot 2 \\
11 \cdot 0\end{array}$ \\
\hline
\end{tabular}


amounts to two normal sera. The titre of one serum with haemoglobin in agar gel was 1 in 32 . The precipitating factor was completely absorbed from $1 \mathrm{ml}$. by $10 \mathrm{mg}$. haemoglobin, and this formed $0.0112 \mathrm{~g}$. precipitate.

Half the amount of haemoglobin for complete absorption ( $5 \mathrm{mg}$. per $\mathrm{ml}$. serum) was added to the serum (15 ml.) in a tube which was incubated for three days at $37^{\circ} \mathrm{C}$. The supernatant was removed and tested with more haemoglobin in agar gel; its titre remained unchanged at 1 in 32. The dried precipitate weighed $0.0026 \mathrm{~g}$. per $\mathrm{ml}$. serum.

Increasing amounts of fresh haemoglobin $(1,2$, 4,5 , and $6 \mathrm{mg}$. per ml. supernatant) were added to $3 \mathrm{ml}$. amounts of the supernatant in tubes which were incubated at $37^{\circ} \mathrm{C}$. for a further three days. The remaining precipitating factor was absorbed from the supernatant by about $4 \mathrm{mg}$. haemoglobin per $\mathrm{ml}$. and this amount of haemoglobin formed $0.0084 \mathrm{~g}$. precipitate. Thus when the haemoglobin was added in divided amounts, the total precipitate weighed $0.011 \mathrm{~g}$.

A similar result with the other serum confirmed that the way in which the haemoglobin was added to the serum did not markedly affect the amount of precipitate formed nor the amount of haemoglobin required to absorb the serum completely.

UMBILICAL CORD SERA AND LYSATES Lysates of cord and adult erythrocytes, tested with cord and adult sera in agar gel, formed continuous precipitin bands. Both types of lysates were tested with 13 cord sera and the bands were of similar intensity with seven of the sera; with six the cord lysate band was more marked.

The titres of seven adult sera- 1 in 16 or 1 in $32-$ were the same with both types of lysate. Nineteen cord sera had the same titre with both lysates (three at 1 in 16,16 at 1 in 32) but seven had higher titres with the cord lysate.

Fifty-three normal cord sera were diluted and tested in agar gel with lysate from adult erythrocytes; eight had a titre of 1 in 8,16 of 1 in 16 , and 39 of 1 in 32.

Constant volumes of nine cord sera were tested with increasing amounts of adult haemoglobin ( 3 to $20 \mathrm{mg}$. $/ \mathrm{ml}$. serum). Larger precipitates were formed than had been obtained from adult sera and lysates.

PRECIPITATING FACTOR IN SERUM FRACTIONS Albumin was prepared with trichloracetic acid from 11 sera and with sodium sulphite from five sera. These albumin fractions appeared to be pure when tested by paper electrophoresis. They all gave precipitin bands with lysate in agar gel. The other serum protein fractions produced by salt precipitation did not give this band.

IRON CONTENT OF PRECIPITATES The precipitin band formed by lysate and serum in agar gel gave a weak and irregular haem-iron reaction with o-tolidine, benezidine, or o-anisidine.

The percentage of iron in precipitates from tubes was not constant. The iron content of 132 precipitates ranged from 0 to $0.132 \%$ but was usually below $0.1 \%$ and was unrelated to the proportion of haemoglobin in the lysate-serum mixture.

\section{DISCUSSION}

Although serum precipitates with lysed erythrocytes, the usually accepted characteristics of an antigen-antibody reaction are absent. Antibodies are serum globulins but the serum factor of this reaction is in the albumin. There is no zone of inhibition in the presence of either excess serum or haemoglobin. Addition of haemoglobin to serum in equivalent or divided amounts does not alter the total precipitate nor the quantity of haemoglobin required to absorb the serum completely. Although the foetus does not produce antibodies, cord serum reacts as strongly as adult serum. A maternal origin for the precipitating factor in cord serum is unlikely since cord sera have a greater affinity for cord than for adult lysates and this difference is not shown by adult sera.

Neither ABO antibodies nor haptoglobins are involved, as both are globulins and are not usually present in cord serum. Moreover, the haptoglobins in $1 \mathrm{ml}$. serum are saturated by about $1.35 \mathrm{mg}$. haemoglobin but about $10 \mathrm{mg}$. is required to saturate the serum in this reaction. The haptoglobinlysate complex does not precipitate and, when separated from other parts of the serum by electrophoresis, stains readily for iron.

The lysate-serum complex precipitates and probably does not contain iron. The greatest amount of iron found in any precipitate is $0.132 \%$, the usual values being much less and bearing no relation to the proportion of haemoglobin in the lysate-serum mixture. The precipitin band in agar stains irregularly for haem-iron. This suggests that the minute amounts of iron in the precipitate could have been included non-specifically.

Burnet and Fenner (1949) consider that serum albumin forms a reversible combination with a large variety of molecules and transports them through the plasma. Precipitation occurs with all normal human sera and all, including the isologous, normal haemoglobins. Cord sera form more precipitate than equivalent amounts of adult sera and tend to react 
more strongly with cord than with adult lysates, possibly because of the increased haemolysis which takes place during the change from the foetal to the adult state. Therefore whether or not this is an antigen-antibody reaction in the accepted sense, it could be part of the fundamental physiological reaction for the removal of products of erythrocyte lysis.

\section{REFERENCES}

Burnet, F. M., and Fenner, F. (1949). The Production of Antibodies, 2nd ed., p. 8. Macmillan, Melbourne.

Debro, J. R., Tarver, H., and Korner, A. (1957). J. Lab. clin. Med., 50, 728.

Peetoom, F., Rose, N., Ruddy, S., Micheli, A., and Grabar, P. (1960). Ann. Inst. Pasteur, 98, 252.

Trinder, P. (1956). J. clin. Path., 9, 170

Wilson, J. F., and Jobling, Dorothy, M. (1961). Nature (Lond.), 190, 550. 